\title{
Pemberdayaan Masyarakat dalam Pengembangan Taman Wisata Alam Gunung Permisan sebagai Kawasan Ekowisata
}

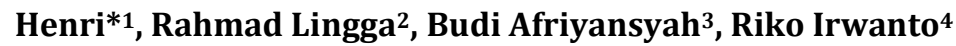 \\ 1,2,3,4Program Studi Biologi, Fakultas Pertanian, Perikanan dan Biologi, Universitas Bangka Belitung \\ *e-mail: biology.henry@gmail.com
}

\begin{abstract}
This community service is carried out to optimize the knowledge and empowerment of the community in Permis Village in developing the Mount Permisan Nature Tourism Park (NTP) area as an ecotourism area in a sustainable manner. The method used in this activity is direct socialization to the community and FGD (Focus Group Discussion). The results showed that the NTP of Mount Permisan has the potential to be developed into an ecotourism area based on its potential. This is also supported by the enthusiasm of the village community in sustainably managing the environment. The need for collaboration in developing the NTP of Mount Permisan area so that together they can become a pioneer of conservation, maintain the community's socio-cultural identity, and become one of the pillars in improving the community's economy. This service can indirectly increase people's knowledge in managing natural resource potentials; fostering a mindset to collaborate to form a community that has the potential to increase people's economic income; and an initiative to form tourism-aware community groups as an effort to manage the environment sustainably.
\end{abstract}

Keywords: Ecotourism, community empowerment, NTP of Mount Permisan

\begin{abstract}
Abstrak
Pengabdian masyarakat ini dilakukan dengan tujuan dapat mengoptimalisasikan pengetahuan dan pemberdaayaan masyarakat di Desa Permis dalam mengembangkan kawasan Taman Wisata Alam (TWA) Gunung Permisan sebagai kawasan ekowisata secara berkelanjutan. Metode yang digunakan dalam kegiatan ini yaitu dengan cara sosialiasi secara langsung kepada masyakat dan FGD (Focus Group Discussion). Hasil yang didapatkan bahwa TWA Gunung Permisan memiliki potensi untuk dapat dikembangkan menjadi kawasan ekowisata berdasarkan potensinya. Hal ini juga didukung dengan antusiasnya masyarakat desa dalam mengelola lingkungan secara berkelanjutan. Perlunya kolaborasi dalam mengembangan kawasan TWA Gunung Permisan sehingga secara bersama-sama dapat menjadi pelopor konservasi, mempertahankan identitasi sosial budaya masyakat, dan menjadi salah satu penompang dalam meningkatkan perekonomian masyarakat. Pengabdian ini secara tidak langsung dapat meningkatnya pengetahuan masyarakat dalam mengelola potensi sumberdaya alam; menumbuhkan mindset untuk berkolaborasi membentuk suatu komunitas yang berpotensi dapat meningkatkan pendapatan ekonomi masyarakat; dan adanya inisiatif pembentukkan kelompok masyarakat sadar wisata sebagai upaya pengelolaan lingkungan yang berkelanjutan.
\end{abstract}

Kata kunci: Ekowisata, pemberdayaan masyarakat, TWA Gunung Permisan

\section{PENDAHULUAN}

Praktek kepariwisataan dalam mengelola destinasi pariwisata saat ini memerlukan pendekatan tata kelola yang mengadopsi prinsip-prinsip pembangunan kepariwisataan yang berkelanjutan. Pariwisata yang baik tentu akan memperhatikan aspek-aspek penting dalam pengembanganya dengan mengoptimalkan pemanfaatan sumberdaya alam dan pelibatan masyarakat lokal sehingga terjalin nilai jasa lingkungan berkelanjutan untuk masa depan (Baggio et al., 2010). Masyarakat lokal sebagai bagian penting dalam pengelolaan sumberdaya alam tentunya memerlukan sinergi yang tepat terhadap pemangku kepentingan yang bergerak dalam pengembangan pariwisata. Hal ini sebagai bentuk upaya mempertahankan aspek sosial budaya masyarakat yang melekat saat ini selain aspek ekonomi dan ekologinya (Laws et al., 2011). 
Ekowisata merupakan salah satu bentuk pariwisata yang berkelanjutan dan pada umumnya ekowisata ini bagian penting dari upaya konservasi dikarenakan memiliki unsur pendidikan apabila dikeoloa dan secara profesional. Selain itu, pada prakteknya ekowisata juga harus mampu meningkatkan perekonomian masyarakat lokal serta menerapkan konsep konservasi lingkungan dalam pengelolaannya (Nugroho, 2011). Ekowisata dapat dijadikan suatu konsep yang sangat tepat dan berguna dalam menjaga ekosistem di areal yang masih alami, bahkan dalam proses pengembangannya ekowisata juga menggunakan strategi konservasi (Henri et al., 2017).

Konsep ekowisata pada saat ini telah dikenal dengan baik dan sudah sangat populer, bahkan daerah-daerah perdesaan saat ini banyak mengklaim sebagai desa ekowisata, walaupun terkadang konsepnya sesuai atau tidak dengan definisi ekowisata itu sendiri (Scott, 2011). Kolaborasi adalah prinsip kunci dalam pendekatan ekowisata berbasis masyarakat di sebagian besar negara berkembang. Pemberdayaan dan partisipasi masyakat dalam ekowisata membawa hasil yang beragam pada konservasi keanekaragaman hayati dan mata pencaharian masyarakat karena keterlibatannya dalam berbagai pemangku kepentingan seperti: desain, perencanaan, dan pelaksanaan ekowisata (Stone, 2015).

Tawan Wisata Alam (TWA) Gunung Permisan memiliki luas kawasan $\pm 3.149,69$ hektar berdasarkan SK Menteri Lingkungan Hidup dan Kehutanan Nomor: SK. 580/ Menlhk/ Setjen/PLA.2/7/2016 tanggal 27 Juli 2016 tentang Penetapan fungsi dalam fungsi pokok kawasan suaka alam dan kawasan pelestarian alam sebagai Hutan Taman Wisata Alam Gunung Permisan, di Kabupaten Bangka Selatan Provinsi Kepulauan Bangka Belitung. Kawasan TWA Gunung Permisan memiliki potensi yang dapat dikembangkan seperti potensi jasa lingkungan dan potensi wisata (BKSDA SUMSEL, 2020).

Pada saat ini, ekowisata bukan hanya berfokus pada peningkatan ekonomi masyarakat lokal saja, akan tetapi perlu diperhatian juga bagiamana upaya konservasi yang dilakukan dalam menjaga eksistensi sumberdaya alam tersebut dan serta sosial budaya masyarakat yang ada di kawasan tersebut sehingga tidak meningbulkan konflik dan dampak negatif dengan adanya ekowisata. Ekowisata apabila dirancang secara berkelanjutan tentu akan dampak positif terhadap sumberdaya alam dan masyarakatnya. Oleh karena itu, maka perlu optimalisasi pengetahuan dan pemberdaayaan masyarakat di Desa Permis dalam mengembangkan kawasan Taman Wisata Alam Gunung Permisan sebagai kawasan ekowisata secara berkelanjutan.

\section{METODE}

\section{Metode Realisasi Pemecahan Masalah}

Persiapan Kegiatan

Adapun tahapan-tahapan sebelum melakukan kegiatan ini, maka perlu dilakukan persiapan-persiapan sebagai berikut:

1. Melakukan survei awal mengenai potensi dari desa yang akan disosialisasi, yaitu dari kondisi alam dan masyarakat disekitarnya

2. Menentukan waktu yang tepat untuk melaksanakan kegiatan pengabdian

3. Menentukan sasaran atau peserta kegiatan pengabdian kepada masyarakat yang sesuai dengan tema sosialisasi yang akan dilakukan

4. Menentukan dan melakukan persiapan materi pengabdian yang akan disampaikan kepada peserta kegiatan agar mudah dipahami dan dimengerti pada saat kegiatan dilakukan

\section{Pelaksanaaan Kegiatan}

Pelaksanaan kegiatan pengabdian kepada masyarakat ini dilakukan pada 1-3 Maret 2019. Kegiatan ini dihadiri oleh 39 peserta yang terdiri dari 20 tokoh penggiat lingkungan/masyarakat di Desa Permis dan 19 mahasiswa biologi yang saat pelaksanaan 
kegiatan sedang melakukan studi lapang yang lokasinya bertepatan di Taman Wisata Alam (TWA) Gunung Permisan. Kegiatan ini dilaksanakan di Desa Permis, Kecamatan Simpang Rimbas, Kabupaten Bangka Selatan. Kegiatan dialakukan dengan penyampaian materi terlebih dahulu diikuti dengan diskusi baik dengan masyarakat yang ada di Desa Permis maupun dengan mahasiswa yang sedang melakukan studi lapang di TWA Gunung Permisan.

\section{Khalayak Sasaran}

Pengabdian ini dilakukan dengan melibatkan masyarakat Desa Permis secara langsung yang tergabung di Karang Taruna maupun kelompok Pembina Kesejahteraan Keluraga (PKK) ditambah dengan mahasiswa biologi yang sedang melakukan kegiatan studi lapang di Taman Wisata Alam Gunung Permisan. Pengabdian ini dilakukan dengan memfokuskan kajian pengembangan Taman Wisata Alam Gunung Permisan yang terletak di Kabupaten Bangka Selatan. Hal ini dikarenakan kawasan tersebut berpotensi dikembangkan sebagai tempat ekowisata sebagaiman salah satu fungsi TWA itu sendiri yang telah ditetapkan oleh Pemerintah Provinsi Kepulauan Bangka Belitung dan Pemerintah Kebupaten Bangka Selatan.

\section{HASIL DAN PEMBAHASAN}

\section{Hasil}

Sosialisasi dilakukan dengan masyarakat Desa Permis, Perangkat Desa serta mahasiswa yang sedang melakukan kegiatan Studi Lapang terlebih dahulu dalam bentuk small group discussion, kemudian kegiatan ini berlanjut dengan bentuk sosialisasi yang lebih besar dalam bentuk FGD (Focus Group Discussion).

Adapun hasil diskusi tersebut sebagai berikut:

1. TWA Gunung Permisan terdiri dari lima (5) bukit, diantaranya: Bukit Nenek, Bukit Nangka, Bukit Meninjen Tua, Bukit Meninjen Muda, dan Bukit Jering. Kawasan TWA ini dapat dikembangkan sebagai wisata religi karena memiliki gua untuk dikunjungi. Selain itu, potensi yang dikembangkan lain yaitu dari segi jasa lingkungannya karena memiliki beberapa anak sungai untuk dikembangkan sebagai salah satu moda transportasi alternatif untuk menikmati suasa hutan disekitarnya.

2. Masyarakat Desa Permis mempunyai komitmen untuk mempertahankan kekayaan sumberdaya alam sebagai salah satu bentuk kawasan yang dapat dijadikan pemnanfaatan sebagai jasa lingkungan berupa ekowisata dengan melibtakan masyarakat dengan pemerintah daerah/kabupaten.

3. Masyarakat Desa Permis perlu dukungan untuk mendata mengenai potensi yang ada baik dari kekayaan flora dan faunanya sehingga akan menjadi bahan pertimbangan dalam mengembangkan sebagai kawasan wisata alam.

4. Masyarakat Desa Permis berharap mendapat dukungan dari pemerintah provinsi, LSM lingkungan, dan tenaga professional terutama peneliti di bidang lingkungan dalam mengkaji lebih lanjut mengenai potensi Taman Wisata Alam yang di jadikan wisata alam ataupun dijadikan kawasan ekowisata

5. Masyarakat Desa Permis menerima secara terbuka bagi perguruan tinggi maupun para peneliti yang mau mengkaji mengenai potensi dan upaya konservasi yang ada saat ini.

6. Ibu-ibu PKK yang menjadi peserta FGD mengharapkan pendampingan untuk menciptakan suatu produk khas daerah seperti cindera mata.

7. Masyarakat Desa Permis juga mengharapkan bantuan dalam membentuk master plan dalam pengembangan kawasan wisata alam terutama di TWA Gunung Permisan dan diharapkan sebagai sarana edukasi atau penelitian. 

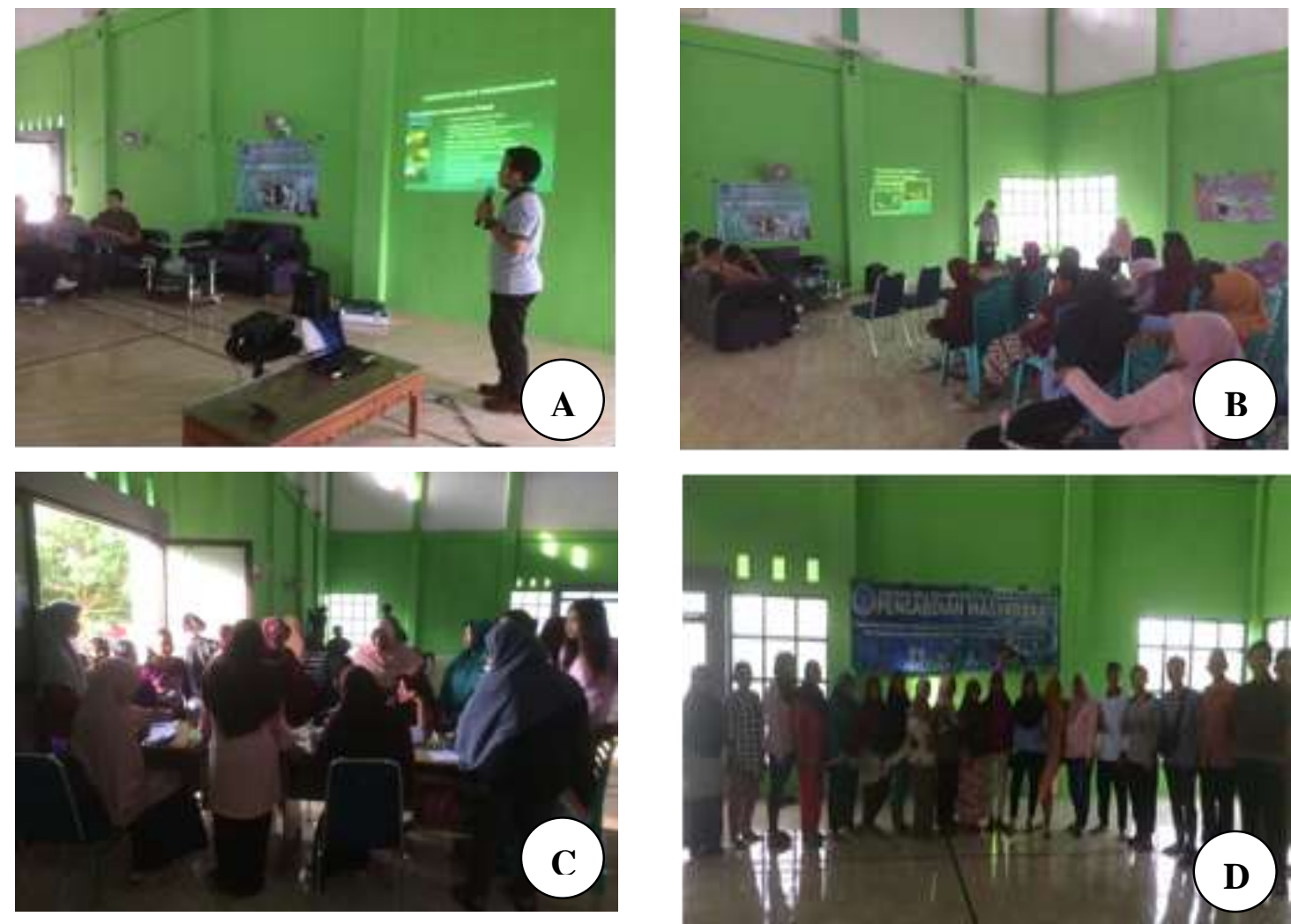

Gambar 1. Kegiatan FGD pengabdian kepada masyarakat, (A dan B) Pemaparan materi konsep pengembangan ekowisata; (C) Diskusi dengan ibu-ibu PKK di Desa Permis; dan (D) Foto bersama setelah kegiatan pengabdian kepada masyarakat.

\section{Pembahasan}

Potensi yang ada pada kawasan TWA Gunung Permisan menjadi suatu hal yang penting bagi masyakat lokal untuk mengembangnya secara bersama-sama. Pengembangan kawasan TWA Gunung Permisan dapat menjadi segmen kegiatan wisata yang memanfaatkan secara berkelanjutan warisan alam dan budaya (religi), mendorong pelestariannya, dan berupaya membentuk kesadaran lingkungan melalui interpretasi lingkungan dengan mempromosikan kesejahteraan masyarakat yang terlibat. Menurut Nunkoo \& Gursoy (2012), menyatakan bahwa dukungan dari masyarakat lokal merupakan bagian integral dari konsep ekowisata yang seimbang. Pengembangan ekowisata apabila direncanakan dengan baik, maka ekowisata dapat memberikan manfaat ekonomi yang besar bagi penduduk lokal. Hal lain yang perlu diperhatikan dalam upaya melindungi dan melestarikan kawasan TWA Gunung permisan maka masyarakat sekitar juga perlu pemberian pemahaman kesadaran secara hukum dalam pengelolaan kawasan konservasi tersbut (Lanini \& Syafiuddin, 2020).

Berdasarkan hasil FGD dengan masyarakat lokal bahwa perlunya pemahaman dalam mengingat konsep ekowisata yaitu menekankan pada kegiatan berbasis pendidikan dan pembelajaran. Selain itu, pengetahuan tentang lingkungan secara ekologis dan gagasan ilmiah tentang kearifan masyarakat lokal juga harus dikembangkan dan didukung oleh para pemangku kepentingan. Oleh karena itu, kolaborasi dari berbagai pemangku kepentingan pariwisata eksternal sangat penting. Hal ini sesuai dengan Henri \& Ardiawati (2020), bahwa peran masyarakat dan pemangku kepentingan (stakeholders) menjadi bagian penting dalam pengembangan potensi dalam upaya meningkatkan pendapatan masyarakat lokal.

Menurut Butarbutar \& Soemarno (2013), ekowisata bukan hanya sebatas tinggi jumlah kunjungan wisatawan sebagai daya dukungnya, akan tetapi perlu perhatian khusus juga terhadap aspek lainnya, seperti: (1) daya dukung ekologi, dimana sumberdaya alam harus 
berimabang dengan kebutuha wisatawan, (2) daya dukung fisik, hal ini berkaitan dengan peningkatan saran dan praarana pendukung dalam pemenuhan kebutuhan wisatawan, (3) daya dukung sosial, kegiatan wisatawan tidak serta-merta merubah kondisi sosial masyarakat yang sudah melekat dan diupayakan tidak menimbulkan dampak negatif terhadap masyarakat tersebuty, dan (4) daya dukung ekonomi, ekowisata harus mampu meningkatkan kepentingan perekonomian masyarakat lokal dari hasil pengembangan ekowisata..

Pengembangan ekowisata berbasis masyarakat ini secara sederhana merupakan bentuk alternatif pengembangan pariwisata yang berkonsentrasi pada partisipasi masyarakat dalam semua proses mulai dari perumusan ide hingga perencanaan, pelaksanaan, pengelolaan, pemantauan, evaluasi, dan pembagian manfaat (Schott \& Nhem, 2018). Hal ini juga memiliki kesamaan dengan pariwisata berkelanjutan dengan mencakup dimensi sosial budaya, lingkungan dan ekonomi (Dangi \& Jamal, 2016).

\section{Dampak}

Pengabdian kepada masyarakat yang dilakukan ini diharapkan memberikan dampak ketermanfaatan secara langsung maupun tidak langsung kepada masyarakat diantaranya:

1. Meningkatnya pengetahuan masyarakat dalam mengelola potensi sumberdaya alam dengan adanya sosialisasi dan pendampingan secara singkat saat pelaksanaan kegiatan

2. Menumbuhkan mindset untuk berkolaborasi membentuk suatu komunitas yang berpotensi dapat meningkatkan pendapatan ekonomi masyarakat dari industri rumahan menjadi UMKM yang dapat dikelola secara bersama-sama

3. Adanya inisiatif Pemerintah Desa dan Karang Taruna untuk mengajak pemuda-pemudi di Desa Permis untuk membentuk POKDARWIS (Kelompok Masyarakat Sadar Wisata) berdasarkan potensi desa yang ada sebagai upaya pengelolaan lingkungan yang berkelanjutan.

\section{KESIMPULAN}

1. Kawasan Taman Wisata Alam Gunung Permisan mempunyai potensi untuk dijadikan kawasan ekowisata berdasarkan potensi yang ada dan perlu adanya upaya konservasi yang diterapkan oleh masyarakat sehingga menjadi kawasan pariwisata yang berkelanjutan.

2. Pemberdayaan masyakat menjadi faktor penting dalam menggerakan potensi yang ada supaya dapat meningkatkan pendapatan ekonomi masyarakat.

3. Perlunya kolaborasi guna menjalin kerjasama yang berkesinambungan dan dengan tetap menjaga kearifan lokal sebagai ciri khas atau identitas daerah.

\section{UCAPAN TERIMA KASIH}

Terima kasih atas support dari Pemerintah Desa Permis, Karang Taruna dan kelompok Pembina Kesejahteraan Keluraga (PKK) atas kesedian waktu mengikuti kegiatan dan telah memberikan ruang untuk kegiatan pengabdian yang dilakukan ini.

\section{DAFTAR PUSTAKA}

Baggio, R., Scott, N., \& Cooper, C. (2010). Improving tourism destination governance: a complexity science approach. Tourism Review, 65(4), 51-60.

BKSDA SUMSEL. (2020). Menguak Keindahan Alam TWA Gunung Permisan. https://bksdasumsel.org/2020/08/11/menguak-keindahan-alam-twa-gunung-permisan/

Butarbutar, R., \& Soemarno, S. (2013). Environmental Effects Of Ecotourism In Indonesia. Journal of Indonesian Tourism and Development Studies, 1(3), 97-107. 
Dangi, T. B., \& Jamal, T. (2016). An integrated approach to "sustainable community-based tourism." Sustainability, 8(5), 1-32.

Henri, H., \& Ardiawati, S. (2020). Ecotourism Development of Munjang Mangrove Forest and Conservation Efforts Based on Community Approach. BIOLINK (Jurnal Biologi Lingkungan Industri Kesehatan), 7(1), 106-116.

Henri, Hakim, L., \& Batoro, J. (2017). Ecotourism Development Strategy of Pelawan Forest in Central Bangka , Bangka Belitung. Journal of Indonesian Tourism and Development Studies, 5(3), 145-154.

Lanini, A., \& Syafiuddin, I. (2020). Peningkatan Kesadaran Hukum Tentang Konservasi Lingkungan Bagi Masyarakat Watutela. Dinamisia: Jurnal Pengabdian Kepada Masyarakat, 4(4), 701-707.

Laws, E., Richins, H., Agrusa, J., \& Scott, N. (2011). Tourist destination gtovernance: practice, theory and issues. Wallingford: CAB International.

Nugroho, I. (2011). Ekowisata dan pembangunan berkelanjutan. Yogyakarta: Pustaka Pelajar.

Nunkoo, R., \& Gursoy, D. (2012). Residents' support for tourism. An Identity Perspective. Annals of Tourism Research, 39(1), 243-268.

Schott, C., \& Nhem, S. (2018). Paths to the market: analysing tourism distribution channels for community-based tourism. Tourism Recreation Research, 43(3), 356-371.

Scott, D. (2011). Why sustainable tourism must address climate change. Journal of Sustainable Tourism, 19(1), 17-34.

Stone, M. T. (2015). Community-based ecotourism: A collaborative partnerships perspective. Journal of Ecotourism, 14(2-3), 166-184. 